\title{
The Construction of the Catholic Church in Nikolsk-Ussuriysky (Ussuriysk) in the Light of the Russian State Historical Archive of the Far East in Vladivostok
}

Zarys treści: W artykule zaprezentowano dokumenty dotyczące budowy kościoła katolickiego w Ussuryjsku (Nikolsku Ussuryjskim), które przechowywane są w Rosyjskim Państwowym Archiwum Historycznym Dalekiego Wschodu we Władywostoku. Dokumenty obejmują okres od 1912 do 1921 r. Budowa kościoła zakończyła się lokalnym skandalem i konfliktem w środowisku miejscowych Polaków, stanowiących zdecydowaną większość społeczności katolickiej w Ussuryjsku.

Outline of content: The article presents the documents related to the construction of the Catholic church in Ussuriysk kept in the Russian State Historical Archive of the Far East in Vladivostok. The documents cover the period between 1912 and 1921. The building of the church proced to be divisive for the local Polish community, who constituted a large part of the Roman Catholic faithful in Ussuriysk.

Słowa kluczowe: Polacy w Rosji, Ussuryjsk, Daleki Wschód, katolicyzm w Rosji

Keywords: Poles in Russia, Ussuriysk, Far East, Catholicism in Russia

Ussuriysk is located about $100 \mathrm{~km}$ north of Vladivostok in the Far East that is part of the Russian Federation. At present, the city is inhabited by approx. 170,000 inhabitants, due to which it ranks second, after Vladivostok, in terms of size among the urban centres located in Primorsky Krai. ${ }^{1}$ The city is 150 years old and its history dates back to 1866, when a dozen or so families from Voronezh and Astrakhan

\footnotetext{
1 Численность населения Российской Федерации по мунииипальным образованиям, http://www.gks.ru/wps/wcm/connect/rosstat_main/rosstat/ru/statistics/publications/catalog/ afc8ea004d56a39ab251f2bafc3a6fce (access: 31 August 2016).
} 
governorates established the village of Nikolskoye. The year 1891, when work on the construction of the Trans-Siberian Railway began, was a turning point for the settlement. ${ }^{2}$ In 1893, railway traffic between Vladivostok and Nikolskoye was opened, which greatly stimulated economic development. As a consequence, Nikolskoye greatly expanded, which led to the granting of city status in 1898. Its name was also changed to Nikolsk-Ussuriysky. ${ }^{3}$

Poles began to appear in the city as well. During the first all-Russian census, it was found that 169 Polish people lived in the entire Ussuriysk Oblast in $1897 .{ }^{4}$ Most of them concentrated in its administrative centre, i.e. Nikolskoye. It can be assumed that the number of Catholics was slightly higher, and probably did not exceed 200 people. ${ }^{5}$ Thus, it was not a sizeable community, although it was growing fast. ${ }^{6}$ Local historians from Primorsky Krai believe that at the beginning of the $20^{\text {th }}$ century, the number of Catholics, including soldiers stationed in

2 The route from Moscow to Vladivostok counts more than 9,000 kilometres and is the longest railway in the world. However, historically, the Trans-Siberian railway line is only the section running from the town of Miass (in Chelyabinsk Oblast) to Vladivostok. It was built between 1891 and 1916.

${ }^{3}$ For the history of Ussuriysk in the $19^{\text {th }}$ c. see: В. Калинин, Краткий исторический очерк города Никольск-Уссурийского, Владивосток, 2015. In the $20^{\text {th }}$ century, the city changed its name twice. In 1935 to Voroshilov, and in 1957 to Ussuriysk, which it has retained ever since.

${ }^{4}$ Первая всеобщая перепись населения Российской Империи 1897 г. Распределение населения по родному языку и уездам Российской Империи кроме губерний Европейской России, http://demoscope.ru/weekly/ssp/emp_lan_97_uezd.php?reg=691 (access: 31 August 2016).

5 This conclusion can be drawn from the fact that in Primorskaya Oblast (Nikolskoye was part of it) the average number of Catholics was $14 \%$ higher than the number of Poles. 3,198 Poles lived in this administrative unit in 1897, while there were 3,690 Catholics. As regards only the cities in Primorskaya Oblast (it should be taken into account that Nikolskoye was not granted city status until 1898, i.e. one year after the census), the number of Poles was 1,362, and there were 1,590 Catholics. Cf. Первая всеобщая перепись населения Российской Империи 18972. http://www.demoscope.ru/weekly/ssp/census.php?cy=0 (access: 31 August 2016).

${ }^{6}$ It should be taken into consideration that the number of Poles in the Far East of Russia was probably increasing at the beginning of the $20^{\text {th }}$ century, but it is difficult to provide accurate data. After 1897, another census was conducted only in 1926, that is already after the establishment of independent Poland and the conclusion of the Treaty in Riga, i.e. after the events that caused the mass departure of Poles from Russia to their homeland. Nevertheless, the results of the census conducted in 1926 show that 316 Poles lived in Nikolayevska Oblast (Nikolsk-Ussuriysky was its administrative centre) that year. Cf. Всесоюзная перепись населения 1926 года. Национальный состав населения по регионам РСФСР, http://demoscope.ru/weekly/ssp/rus_ nac_26.php?reg=1410 (access: 31 August 2016). Two partial censuses were conducted in Russia between 1897 and 1926. In 1920, one of them was held in the territories controlled by the Bolsheviks at that time, and was aimed at gathering information on the state of agriculture. By contrast, in 1923, a city census was conducted. However, it did not cover the Far East, where, in the years 1920-1922, an independent state under the name of the Far Eastern Republic de facto existed. In addition, from 1921 to 1922, there was a quasi-state called Priamursky Zemsky Krai, the centre of which was Vladivostok. Neither the 1920, nor the 1923 censuses took into account the Poles and Catholics remaining in the Far East. 
the garrison in Nikolsk-Ussuriysky (it was there since 1872), amounted to about $2,000 .^{7}$ Most of them were Poles. They were not large enough a population to attract the attention of historians. For this reason, researchers dealing with the history of Catholicism in the Far East and the Polish diaspora usually omit NikolskUssuriysky in their analyses. Issues such as the formation of the Catholic community or the participation of Poles in the socio-political life of the place have not been thoroughly investigated. These subjects have been explored much better with regard to larger centres such as Vladivostok or Harbin. However, there are publications in which the issue of Poles in Nikolsk-Ussuriysky has been addressed. This subject was raised, among others, by Oleg Yeltchaninov in his work written in the Czech language Ustanovení katolické církevní organizace, její vývoj na Ruském Dálném Východè, od konce 19. století do 30. let Sovětského obdobi ${ }^{8}$ However, it has the disadvantage of containing very few footnotes, which makes it difficult to verify the sources on which it was based. An interesting monograph is one written by Miroslava Yefimova under the title Harsh Vineyard: A History of Catholic Life in the Far East ${ }^{9}$ which is the most extensive work on the question of Catholics in the Far East of Russia. However, in many places it does not provide any sources of information either. The topic of the Catholic Church in Nikolsk-Ussuriysky was also discussed by local researchers from Primorsky Krai. One of the first to do so was Oleg Kovalenko, who in 2005 published the article "Уссурийский костел" in the local journal Уссурийский краеведческий вестник. ${ }^{10}$ Much interesting information about both the Church and Catholics can be found on the Internet forums where inhabitants of Ussuriysk discuss the history of their city. ${ }^{11}$

Looking at small Polish/Catholic communities, like the one in NikolskUssuriysky, complements and enriches the knowledge about the organization and life of Poles living in the Far East of Russia in the late $19^{\text {th }}$ and early $20^{\text {th }}$ centuries. This can be done by studying e.g. the history of the construction of the Catholic church in this city, to which this article is devoted.

A significant number of documents on the construction of the church in Nikolsk-Ussuriysky are currently stored in Vladivostok in the Russian State Historical Archive of the Far East (in Russian: Российский государственныцй исторический архив Дальнего Востока), located in 10a Aleutska Street

\footnotetext{
7 А. Хвалин, Из истории римо-католичества на Дальнем Востоке, http://ruskline.ru/analitika/2011/12/09/vlast_rimskogo_pontifika_protiv_vlasti_russkogo_carya/ (access: 15 September 2016).

${ }^{8}$ O. Jelčaninov, Ustanovení katolické církevní organizace, její vývoj na Ruském Dálném Východè, od konce 19. století do 30. let Sovětského období, Olomouc, 2013.

9 M. Efimova, Harsh Vineyard: A History of Catholic Life in the Russian Far East, Bloomington, 2008.

10 О. Коваленко, “Уссурийский костел”, Уссурийский краеведческий вестник, 4 (2005).

11 One of the most reliable ones is the forum located at the website http://www.skyscrapercity.com/ showthread.php?t=1595252.
} 
(in Russian: $у л$. Алеутская). Among the archives collected there under no. 614, there is the collection entitled Костельный комитет Никольск-Уссурийского католического прихода. г. Никольск-Уссурийский (The Church Committee of the Nikolsk-Ussyriyskean Catholic parish in Nikolsk-Ussuriysky).

The archival documents indicate that in mid-August 1912 the city duma in Nikolsk-Ussuriysky decided to hand over, free of charge, a plot for the construction of a Catholic church. The plot was located in the western part of the city, between Korfovskaya ${ }^{12}$ and Grodekovskaya ${ }^{13}$ Streets. The Catholic community, however, did not find it suitable, because it was beyond the city centre. For this reason, at the beginning of 1915, parish representatives turned to the city administration with a request to change the allocated parcel. It was justified by its location on the outskirts and far from the inhabitants of the eastern part of Nikolsk-Ussuriysky. Catholics suggested that, in exchange, the local authorities could allocate a plot of land for the erection of the church near the city centre, i.e. the one located on the corner of Pushkinskaya ${ }^{14}$ and Nikolayevskaya Streets, where an old cemetery had been previously located. Upon receiving this proposal, the city administration sent a special commission, which in mid-January carried out an on-site visit to the indicated place. It appears from the records of its activities that, according to its members, the parcel could have been handed over to the Catholic parish, but on one condition: the church could be no closer than 15 fathoms ${ }^{15}$ to Nikolayevskaya Street. It was stated in the justification that there were still graves in this area, the damage of which was unacceptable. If this condition were met, the Catholic church would be situated outside of the former cemetery. The commission did not identify any other obstacles. Based on the results of its work, the city administration proposed to hand over, free of charge, a parcel of 559,29 square fathoms to the Roman Catholic parish in Nikolsk-Ussuriysky ${ }^{16}$ for the sole purpose of erecting a church and chapel there, subject to the following conditions: 1) never to erect any structures in the parcel area up to 15 meters along Nikolayevskaya Street to Pushkinskaya Street, and 2) when the Roman-Catholic parish is liquidated or relocated, the whole parcel would be immediately returned to the city, free of charge, as a gift from the parish.

However, the city duma prevented the formalization of the handover of the plot. On 10 February 1915, in a secret ballot, fifteen of its members objected to it

12 Korfovskaya Street was named so to commemorate Andrei Korf, who in the years 1884-1893 was the general governor of Priamursky Zemsky Krai. Today, the street's name is Plekhanova (in Russian: Плеханова).

13 Grodekovskaya Street was named in honour of Nikolai Grodekov, an ataman of the Priamursky Cossack Forces. It is now called Oktyabrskaya (in Russian: Октябрьская).

${ }_{14}$ Pushkinskaya Street has retained its name to date.

15 That is 32 metres. According to the Tsar Nicholas I's directive of October 1835, 1 fathom was equal to $2.1336 \mathrm{~m}$.

16 That is approx. $1,193 \mathrm{~m}^{2}$. 
(with twelve who voted "for" and with one abstention) and rejected the Catholics' request and took the position that they should choose another free plot for their church and report it to the city administration. ${ }^{17}$ However, the church-building committee appointed by the Catholic community had information that the city administration had no free plot of land available in the central part of the city any more. Therefore, the committee decided to purchase a real property that would suit the needs of the parish. According to the committee members, the fact that Catholics did not live in a particular part of the city, but were scattered over a large area made it necessary to build a church in the centre of NikolskUssuriysky. As a result of this, at the end of February 1915, the committee submitted a petition to the city authorities for the parcel offered to them in August 1912, between Korfovskaya and Grodekovskaya Streets, to be given to the Catholic parish unconditionally, so that it could be sold and the money obtained in this way would be added to the sum collected by the parishioners for the construction of the church. ${ }^{18}$ This was justified by the fact that purchasing the suitable plot of land would be too much of a financial burden for the committee, which raised funds exclusively from voluntary contributions from local Catholics. The letter stated that should the committee's petition be rejected by the city duma, the committee would ask the city council for a donation in the amount of 2,000 roubles intended for the erection of the church in Nikolsk-Ussuriysky. ${ }^{19}$

On 10 August 1915, the city duma granted their unanimous consent to the sale of the parcel by the Roman Catholic parish and to the allocation of the proceeds from this transaction to the purchase of a new plot of land on which the church was to be erected. ${ }^{20}$ On this occasion, procedural errors in the handover of the plot in 1912 came out, as it turned out that the Priamursky GovernorGeneral $^{21}$ did not approve this decision. Consequently, the duma should not take

17 Russian State Historical Archives of the Far East (hereinafter: RSHAFE), ф. 614, о. 1, д. 2, Переписки и план участка взятого под постройку костела в Никольск-Уссурийске, л. 7, Доклад Никольск-Уссурийской Городской Управы 3 февраля 1915 г. Очередному Собранию Никольск-Уссурийской Городской Думы 10 февраля 19152.

${ }^{18}$ It is difficult to determine whether the church building committee eventually sold the parcel donated by the city. In the archives there is a document stating that at the end of 1916 a committee for the construction of a veterans' centre proposed to purchase this plot from the church building committee for 1,000 roubles (the parcel donated by the city to the Roman Catholic community was adjacent to the parcel where the centre was located). The church building committee agreed to sell the plot, and allocate the money obtained in this way to the construction of the church. Cf. RSHAFE, ф. 614 , о. 1, д. 3, л. 22. It is not known, however, whether the transaction was finalised.

19 RSHAFE, ф. 614, о. 1, д. 2, Переписки и план участка взятого под постройку костела в Никольск-Уссурийске, л. 9, В Никольск-Уссурийское Городское Управление.

20 Ibid., д. 2, Переписки и план участка взятого под постройку костела в НикольскУссурийские, л. 14.

21 The Priamursky Governorate-General was established in 1884. At the time of its inception, it consisted of the following oblasts: Amurskaya, Zabaykalskaya, Primorskaya, and the Vladivostoksky 
a new decision, but only confirm the previous one and apply for its approval in accordance with the applicable legal order. All formal errors were corrected $^{22}$ and on 8 October 1915, the Priamursky Governor-General approved the decision of the Nikolsk-Ussuriyskean duma to hand over the plot of land located at the corner of Korfovskaya and Grodekovskaya Streets to the Roman Catholic parish. ${ }^{23}$

In the autumn of 1915, Father Dominik Mikszyc ${ }^{24}$ was requested by the Mogilevsky Roman Catholic Spiritual Consistory ${ }^{25}$ to send them the plan of the plot intended to be purchased for the construction of the church. ${ }^{26}$ It follows that the Catholics in Nikolsk-Ussuriysky had already chosen the real property to be purchased. It would also explain another document which contains information that, at the turn of 1915 and 1916, the Roman Catholic Spiritual Consistory began talks with the Ministry of Interior about obtaining permission to purchase land for the construction of a church. ${ }^{27}$ By contrast, in April 1916, the Roman Catholic Spiritual Consistory returned to the chaplain of the Priamursky Military District the plans of the plot of land intended to be purchased for the construction of the church, the deed of ownership of the plot of land issued for the name Ushakov, ${ }^{28}$ as well as a preliminary purchase contract of the plot, which had been concluded with its owner. ${ }^{29}$ Most likely, this was related to the withdrawal of the Roman Catholic parish from the land purchase contract. This, in turn, could have been a consequence of a declaration made by Feliks Steckiewicz, one of the richest Poles

military governorate. As a result of administrative reforms, in 1888, the Vladivostoksky military governorate was liquidated, and in 1906 Zabaykalskaya Oblast was detached from the general-governorate and included in the Irkutsk general-governorate, while in 1909, Kamchatskaya Oblast was formed within the Priamursky Governorate-General. The Priamursky Governorate-General was liquidated in 1917.

22 RSHAFE, ф. 614, о. 1, д. 2, Переписки и план участка взятого под постройку костела в Никольск-Уссурийске, л. 10 Доклад Никольск-Уссурийской Городской Управы 7 августа 1915 2.

23 Ibid., д. 2, Переписки и план участка взятого под постройку костела в Никольск-Уссурийске, л. 11 Никольск-Уссурийскому Городскому Голове.

${ }^{24}$ Father Dominik Mikszyc was a chaplain in the Priamursky Military District. He was appointed three times to take up his post in Khabarovsk, in 1872, 1898, 1914. Cf. E. Nowak, Duszpasterstwo wojskowe katolickie i prawosławne w Rosji 1832-1914, Vilnius, 1934, p. 27.

25 The Roman Catholic Archbishopric in Mogilev was established at the end of the $18^{\text {th }}$ century. It covered all of Russia, except the former Polish lands. The Archbishops of Mogilev were metropolitans and effectively administered the Catholic Church in the Russian Empire. They resided in St. Petersburg.

26 RSHAFE, ф. 614, о. 1, д. 2, Переписки и план участка взятого под постройку костела в Никольск-Уссурийске, л. 2.

27 Ibid., д. 2, Переписки и план участка взятого под постройку костела в Никольск-Уссурийске, л. 1.

28 Ushakov's first name remains unknown.

29 RSHAFE, ф. 614, о. 1, д. 2, Переписки и план участка взятого под постройку костела в Никольск-Уссурийске, л. 3. 
living in Nikolsk-Ussuriysky. ${ }^{30}$ Namely, on 10 February, he announced at a Catholic meeting that he would donate the corner plot located between Nikolayevskaya ${ }^{31}$ and Korfovskaya Streets, where there was once a circus, for the erection of the church. The plot was to be handed over free of charge, along its entire length along Nikolayevskaya Street, while along Korfovskaya Street (from Nikolayevskaya Street) at a length of 22 fathoms. ${ }^{32}$ Besides, Steckiewicz also declared that he was ready to sell to the church building committee half of the remaining real property, counting five roubles per square fathom. In addition, he authorized the committee (chaired by Father Mikszyc at that time) to commence preparatory works on the plot. Steckiewicz laid down only one condition, i.e. the church was supposed to have a capacity of minimum 500 people. ${ }^{33}$

At the committee meeting held on $7 \mathrm{March}$, it was decided to start the construction of a stonebuilt church on the plot donated by Feliks Steckiewicz, and to complete all the formalities concerning the acceptance of the donated real property. In addition, it was decided to continue renting the apartment as a house of prayer at Ushakov's house (it was most likely the same person from whom it had been previously planned to purchase land for the construction of the church), located at 61, Pushkinskaya st. The last decision taken at the meeting was to ask Władysław Lindner to design the church. ${ }^{34}$

Among the documents kept in the archives, there are estimates of the construction of the church. It amounted to 28,963 roubles and 81 kopecks, but after a discount it was reduced to 26,242 roubles and 26 kopecks. ${ }^{35}$

On 14 March 1916, the following people appeared at Alexei Tchaga's, a notary in Nikolsk-Ussuriysky: the peasant Ivan Orlov, the burghers Mitrofan and Fyodor Bakalov and the merchants Alexandr Nikitin and Feliks Steckiewicz. There were also witnesses: the burgher Yustin Sakhanov, the merchant Ivan Tchulkov and the peasant Samuil Klitsenko. The appearers stated before the notary that they wanted to effect an act of selling the real property under the following conditions: I. Orlov, M. Bakalov, F. Bakalov and A. Nikitin sell to F. Steckiewicz their right

30 Today, on the social forums where the inhabitants of Ussuriysk discuss their city's history, we can find information that Steckiewicz owned a mineral water factory, a pharmacy, two hotels, a shop, and several multi-family houses for rent. Cf. Уссурийк | Исторические фотографии, http://www.skyscrapercity.com/showthread.php?p=125695006\&langid=5 (access: 15 September 2016).

31 On 21 May 1891, on the occasion of the construction of the Great Siberian Route from Chelyabinsk to Vladivostok, the heir apparent, tsarevich Nikolai Romanov, came to the village of Nikolskoye. To commemorate this event, one of the streets was named Nikolayevskaya (in Russian: Николаевская). Today, the street is named Krasnoznamennaya (in Russian: Краснознаменная).

32 That is approx. $47 \mathrm{~m}$.

33 RSHAFE, ф. 614, о. 1, д. 3, л. 22, Заседание Комитета по постройке костела.

34 Ibid., л. 36.

35 Ibid., д. 8, Смета на постройку Римско-католического костела, л. 1. 
to $4 / 5$ shares in the real property located on the corner of Nikolayevskaya and Korfovskaya Streets at no. 9. The area of the plot was 1,600 square fathoms. ${ }^{36}$ It was sold, along with all the buildings erected on it, to Steckiewicz for 4,500 roubles. ${ }^{37}$

On 27 April 1916, the Mogilevsky Roman Catholic Spiritual Consistory sent from Petrograd ${ }^{38}$ to Father Miszyc instructions on how to proceed in matters related to the parcel in question. They were to tell Feliks Steckiewicz that his gift could be accepted only if it was handed over unconditionally and remained at the exclusive disposal of the church. The document also shows that Steckiewicz had asked the church authorities to allow him and his family to be buried in the crypt of the erected church. The Spiritual Consistory agreed to this under certain conditions. Namely, the donor and members of his family (his legal wife and their children) were to be Roman Catholics on the day of their death, they could not be deprived of a church funeral in the light of the Roman Catholic canon law, and the local state authorities would have to agree to their burial in the church crypt. In the further part of the document it was stated that if Steckiewicz decided to donate the plot under the above conditions, he should draw up a notarized statement, and then send it together with the plan of the donated real property and a notarized copy of the contract of its purchase to the Spiritual Consistory. ${ }^{39}$

One of the documents kept in the archives shows that, on 26 May 1916, Feliks Steckiewicz, in the presence of the notary Alexei Tchaga, entered into a preliminary contract of sale of part of the plot located on the corner of Nikolayevskaya and Korfovskaya Streets in Nikolsk-Ussuriysky with a representative of the Roman Catholic parish. The parties agreed that the parish would pay 2,537 roubles and 50 kopecks for the plot with an area of 507.5 square fathoms. At the signature of the contract, Steckiewicz received an advance in the amount of 100 roubles, while the remainder of the money was to be paid at the signature of the sale-and-purchase agreement. According to the document, it should take place within three years and depended on the decision of the parish. ${ }^{40}$

In mid-1916, members of the Roman Catholic parish actively proceeded to collect financial and material resources for the construction of the church. For instance, there is a document dated 20 June, signed by Jan Jedlikowski, the lessee of a bricks factory, in which he undertook to donate all the bricks needed to erect the church. ${ }^{41}$ Also, Michał Steckiewicz, a forestry industrialist, made a written promise to donate the timber needed to build the church and the fence around it. ${ }^{42}$

36 That is approx. $3,414 \mathrm{~m}^{2}$.

37 Ibid., д. 2, Переписки и план участка взятого под постройку костела в Никольск-Уссурийске, л. 12.

38 In the years 1914-1924, Saint Petersburg was called Petrograd.

39 RSHAFE, ф. 614, о. 1, д. 4, л. 2, Указ.

40 Ibid., д. 3, л. 25, Заявление Феликса Стеикевича.

${ }^{41}$ Ibid., д. 4, л. 5, Подписка Яна Едликовского.

42 Ibid., д. 4, л. 4, Подписка Михаила Стецькевича. 
On 1 July 1916, a meeting of the church building committee was held (its members met at Ushakov's house at 61, Pushkinskaya Street). It was decided to delegate a representative to go to Khabarovsk and meet with the governor-general. He was supposed to obtain consent to organize a lottery, the proceeds from which would be used to erect the church. In addition, the committee instructed its members not to put advertisements or place articles about the construction of the church in regional newspaper Уссурийский Край, or in other newspapers. This issue was taken on by the committee as a whole and it was decided that all advertisements and articles should be submitted to the chairman, vice-chairman or secretary together with one of its members for approval before being sent to the editorial board. ${ }^{43}$ In August, however, the committee decided to organize a fundraiser during each Holy Mass. The issue of the lottery was re-addressed and it was decided to send a request to the governor-general for his consent. At the same time, it was decided to simultaneously ask for permission to organize performances, the proceeds from which were also to be allocated to the construction of the church. ${ }^{44}$

In the autumn of 1916, the Roman Catholic Spiritual Consistory approved the composition of the church building committee in Nikolsk-Ussuriysky. Its members included Father Dominik Mikszyc, the city architect Piotr Spokojski-Francewicz, Doctor Józef Trypolski, Doctor Tadeusz Rechinowski, the engineer Z. Szalowicz, the merchant Feliks Steckiewicz, W. Szydłowski, F. Balcerzak, A. Józefowicz, the technician Władysław Lindner, Father Stanisław Kołodziejczyk ${ }^{45}$ and the entrepreneur Michał Steckiewicz. Fr. Mikszyc ${ }^{46}$ was the chairman of the committee, whereas the audit committee consisted of Władysław Budzynowski, Ignacy Wojtkiewicz, Piotrowski, I. Jedlikowski, L. Sulikowski and Bolesław Medziński. ${ }^{47}$

At the end of 1916, Steckiewicz's disputes with individual members of the church building committee began to emerge. In the minutes of the meeting of 7 November 1916 it was stated that he had made a categorical, groundless and

${ }^{43}$ Ibid., д. 2, Переписки и план участка взятого под постройку костела в Никольск-Уссурийске, л. 16.

${ }^{44}$ Ibid., д. 3, л. 33, Заседание Комитета по постройке костела.

45 O. Jelčaninov wrote that Stanisław Kołodziejczyk came to Nikolsk-Ussuriysky to replace Mikszyc, whom bishop Jan Cieplak, the administrator of the Archdiocese of Mogilev, moved to Nikolayevsk-on-Amur, and then to Harbin. The reason for Mikszyc's recall from NikolskUssuriysky was his failure to submit a proper settlement of accounts in respect of the construction of the church requested by his superiors. Kołodziejczyk also failed to reach an agreement with Steckiewicz on the settlement and after two and a half months in the parish he wrote a letter requesting his "release from duty" in Nikolsk-Ussuriysky. However, he remained in the city and worked in the city school. See: Jelčaninov, Ustanovení katolické církevní organizace, pp. 41-43. The presented document, however, proves that there was a period during which Mikszyc and Kołodziejczyk stayed together in the city and jointly sat on the church building committee.

46 Other documents show that Steckiewicz was vice-chairman of the committee in 1916, but that information is missing from the letter of the Spiritual Consistory.

47 RSHAFE, ф. 614, о. 1, д. 3, л. 32, Указ. 
unlawful request to change the chairman and the treasurer. When the others opposed it, he verbally insulted the chairman, the treasurer, and one of the committee members. He then resigned from his participation in its work and ostentatiously left the meeting. In connection with his behaviour, it was decided to accept Steckiewicz's resignation from the membership in the church building committee. ${ }^{48}$

Committee members reached an agreement at the turn of 1916 and 1917. This fact was affected by Steckiewicz's statement addressed to the committee. He stated that at the meeting on 7 November he announced his resignation from work related to the construction of the church, because he had no strength to fight with some of its members (he did not mention them by name) trying to stop the construction of the church for reasons unknown to him. He emphasized, however, that, having thought the matter through, he had come to the conclusion that if he resigned from his work in the committee, it would suit those interfering with the erection of the temple, and the construction would drag on for several years. For this reason Steckiewicz announced that he took back his words. He added that with regard to the inappropriate way he addressed the committee members, he apologized to the committee, but excluded those members he did not intend to apologize to because they had long deserved such treatment for their disservice to that noble endeavour his was a very strange statement, which was formally an apology, but, in essence, it meant that Steckiewicz persisted with his accusations that some of the committee members were acting to the detriment of the construction of the church. However, in the minutes of the meeting of the committee of 15 January 1917, it was stated that because of Steckiewicz's statement, in which he had apologized for his insults hurled in November, the conflict was deemed to have ended. At the same time, he was entrusted with new tasks related to the construction. For example, he was requested to purchase 200,000 bricks and 100 poods of iron. ${ }^{49}$ In addition, at the April meeting of the committee, he was unanimously elected chairman. ${ }^{50}$

Further disputes between Steckiewicz and other committee members, which never subsided, broke out in 1918. They eventually led to the situation in which the donor went back on his promise to hand over the plot free of charge. Due to the fact that the church was almost finished, Steckiewicz demanded that he be paid not only for the plot, but also for the almost completed church, as well as for the buildings still to be built. Consequently, in the autumn of 1918, he sent to the Roman Catholic parish a draft contract to be concluded with him. He valued the plot along with the buildings erected on it at 120,000 roubles. He took into account the costs of the buildings that had been planned to be built (e.g a school and an apartment for the priest). Under the contract, the parish would pay Steckiewicz

\footnotetext{
48 Ibid., л. 18, Протокол с 7 ноября 1916 г.

49 Ibid., л. 38, Заседание Комитета по постройке костела.

50 Ibid., л. 26, Заседание Комитета по постройке костела.
} 
10,000 roubles per year for a period of 12 years. After that time, the legal title to the plot and all the buildings would be transferred to it. If the parish decided to pay the full amount earlier, then the entire property along with the buildings would be transferred to it respectively earlier. ${ }^{51}$

The contract proposed by Steckiewicz was unfavourable for the parish, especially since the church had been built for the money of the faithful. For this reason, it is not surprising that it was not accepted. Moreover, in October 1918, the general assembly of Catholics in Nikolsk-Ussuriysky authorised the Polish House committee to institute legal proceedings in order to obtain from Steckiewicz compensation for his failure to hand over the keys to the church. However, already on 2 February 1919, another assembly of the faithful decided to suspend the decision taken in October and attempted to reach an amicable settlement in the case. To this end, a nine-person commission ${ }^{52}$ was appointed, headed by Father Julian Brylik, ${ }^{53}$ which was supposed to come to an agreement with Steckiewicz. Within its competence lay the explanation of all the contentious issues between the entrepreneur and the parishioners. The commission was also granted the right to appoint an appraiser who would determine the amount owed by the parishioners to the unrealised donor. It was not only the church that was to be taken into account, but also the wooden building built next to it by Steckiewicz. The commission's decisions would be final and neither party could challenge them. ${ }^{54}$ The maximum time limit for the completion of its work and presentation of a report at the general meeting of Catholics was set for 1 April 1919. The mode and manner of repayment of the parishioners' debt to Steckiewicz, determined by the commis-

51 Ibid., д. 4, л. 1, Письмо с 17 октября 1918 г.

52 Eight members of the commission were selected from among the parishioners, while Father Julian Brylik, who held the decisive vote on all issues being discussed, became its permanent member. Piotr Spokojski-Francewicz, an urban architect, was invited to the commission as an expert in the capacity of an advisor.

53 Julian Brylik (Brylikowski) 1869-1943, PhD in philosophy, a dean of Łask and Staw decanates, honorary canon of the Kalisz collegiate church. He was born on 1 January 1869. At the age of 19, he entered the Higher Seminary at Włocławek, where he completed four courses between 1889 and 1892. Later, he went to study abroad, from where he returned in 1892 with the title of doctor. In that year, he changed his name to Brylik. He was ordained priest on 25 August 1892. In the years 1892-1895, he was a vicar at the Kalisz collegiate church, then a vicar at St. Sigismund's parish in Częstochowa (1895-1899), and for another eight years a vicar at St. Dorothy's post-Dominican church in Piotrków Trybunalski. In 1907, he became the parish priest in Rozprza, and in 1911 the parish priest and dean at Łask. In the years 1914-1920, he stayed in Russia. Upon his return, he took over the parish at Koźminek and was awarded the title of canon of the Kalisz collegiate church. In the years 1922-1926, he was the parish priest in Błaszki and a prefect in the girls' junior high school there. Finally, he became the parish priest in Ciechocinek (1926-1928). In 1928, he retired and left for Hungary. He died in Budapest in July 1943. Cf. Proboszczowie, http://web.diecezja.wloclawek.pl/parafia/ciechocinek/proboszczowie.html (access: 4 June 2016).

54 RSHAFE, ф. 614, о. 1, д. 3, л. 19, Протокол с 2 февраля 1919 г. 
sion, was to be entrusted to the general meeting. Should the commission's work not produce any results, the intention was to return to the suspended provisions adopted in October $1918 . .^{55}$

At the beginning of February 1919, the special commission met with Steckiewicz and the architect supervising the construction of the church, Piotr Spokojski-Francewicz. Its task was to clarify what works had been done in 1918. It follows from the minutes of the meeting that the following works were carried out: 1) foundations and cement stairs at the entrance to the sacristy; 2) the foundations at the main entrance to the church were reinforced; 3) sixteen iron crosses; 4) plastering of all walls and ceilings; 5 ) cement window sills under all windows; 6) all carpentry work related to the doors and windows, including their glazing and painting; 7) insulation of ceilings with felt-covered boards; 8) preparatory works for the concrete floors; 9) laying 1 -inch-thick concrete floors; $\left.{ }^{56} 10\right)$ laying wooden flooring in the organ gallery and in the adjacent room; 11) laying stone steps at the entrance to the altar; 12) the brick foundation under the altar; 13) cleaning the base course; 14) site development plan on the right side of the church; 15) painting ceilings and walls in three colours; 16) frames for windows and doors were fixed in the casings; 17) lime, sand and nails, as well as all windows and doors were purchased; 18) paints and varnishes were acquired; 19) stone steps were laid before the main entrance to the church. ${ }^{57}$

A notification sent to the militia by Fr. Brylik has been preserved in the archives. On 30 April 1919, he noticed a padlocked bolt on the church door. In a letter to the chief of the third militia district in Nikolsk-Ussuriysky, the priest reported that the installed obstacle prevented the church from being opened, celebrating the Mass, and accessing the Eucharistic gifts. Father Brylik stated that he did not know who and why had blocked the door. At the same time, he asked for help in dismantling the obstacle. It was in connection with this incident that on 1 May a militiaman arrived at the church and, in the presence of witnesses, removed the bolt with an axe and opened the exterior door of the temple. He also explained that it had been blocked on the night of 29/30 April by an unknown man. ${ }^{58}$ There were no names appearing in the statement made by the priest, but it is likely that this situation was a result of the conflict between the parishioners and Steckiewicz, even more so considering his difficult character. However, it was possible that this was just an ordinary act of vandalism.

It results from the collected documents that on 4 August 1919 Władysław Szczepański ${ }^{59}$ was unanimously elected chairman of the church building committee. On 24 August, at the general meeting of Catholics, which was attended by twenty-

55 Ibid., д. 6, Протоколь общего собрания прихожан Никольск-Уссур. костела Протокол, л. 1.

56 That is $2.54 \mathrm{~cm}$.

57 RSHAFE, ф. 614, о. 1, д. 5, Акты комисии по постройке костела в Никольск-Уссурийске.

58 Ibid., д. 2, л. 18, Письмо начальнику 3-го района милиции в г. Никольске.

59 Ibid., д. 3, л. 21, Протокол заседания костельного Комитета. 
-one participants, it was decided to elect a church committee. It consisted of authorized representatives of the parish, and its purpose was to deal with all administrative, economic and judicial matters. ${ }^{60}$ The members of the committee included: the lawyer Władysław Szczepański (as the chairman), the brick factory lessee Jan Jedlikowski (as the treasurer), the carpenter Aleksander Ksionek, the locksmith Marcin Krygier and the owner of the house Franciszek Wyszyński. ${ }^{61}$ Father Brylik, in his turn, became the secretary of the committee. ${ }^{62}$

As for the parcel on which the church was erected, the problem concerning the property title to it was not resolved in the years to come. To a large extent, the court public records regarding the session held in Nikolsk-Ussuriysky explain the conflict between Steckiewicz and other parishioners. One document, dating back to 6 December 1921, has survived to the present day. It is unknown whether other court public records have not been preserved, or whether only one court session actually took place. The case against Steckiewicz was filed by the church committee, which was of the opinion that at the time of construction of the church he had squandered 25,000 roubles. The committee's lawyer and witnesses arrived at the hearing. However, the accused failed to turn up in court, although, as recorded, he had been correctly notified. There were ten witnesses, including seven Catholics, two Orthodox and one Buddhist. Three Catholic witnesses said that they did not want to take an oath administered by an Orthodox priest. In the absence of a Catholic priest, they decided to make written statements that their testimony would be true and consistent with their conscience. The attorney of the church committee asked the court to interrogate the three, as well as one Buddhist, without taking an oath, to which the court agreed. The other witnesses took an oath before the Orthodox priest.

The first witness, Yakov Mordovskiy, a representative of the "Kunst and Albers" Department Store ${ }^{63}$ testified that sixteen bills were issued to the church building committee for the purchase of various materials. They were paid for by Steckiewicz as its chairman.

The second witness, Klimentiy Shash, testified that in 1916 he supplied stone for the construction of the church in Nikolsk-Ussuriysky, for which he received 161 roubles and 50 kopecks from Steckiewicz. The witness stated that due to the fact that the purpose of the construction was a charitable one, he sold the goods at a discounted price. He also stressed that he knew that Steckiewicz had not paid with his private money, but from the social funds raised during a collection for the construction of the church.

${ }_{60}$ Ibid., д. 6, Протоколы общего собрания прихожан Никольск-Уссур. костела Протокол, л. 1.

61 Ibid., д. 3, л. 28, Протокол заседания поляков-католиков Никольск-Уссурийска.

62 Ibid., д. 6, Протоколы общего собрания прихожан Никольск-Уссур. костела Протокол, л. 1.

63 "Kunst and Albers" was a German company established by the Germans in the Far East of the Russian Empire in the second half of the $19^{\text {th }}$ century. It operated until the 1930 s. 
The third witness, Chen Moo, ${ }^{64}$ a native of China, testified that the company he worked for had provided the church building committee with a variety of building materials, as well as hired workers for construction work at negative prices. According to the invoices, for the performed works the company was owed 15,483 roubles and 10 kopecks. In 1916 and 1917, it received from the church building committee 8,419 roubles and 65 kopecks. Then, the company was also paid 4,000 roubles, and it renounced the remaining sums to the benefit of the Roman Catholic parish.

The fourth witness, Andrei Navdush, testified that he had received 150 roubles from the church building committee for the building permit design of the church, which was approved in 1916 by the construction department at the Primorskaya Oblast Board. He received the money from Steckiewicz as the chairman of the church building committee. The witness stated that the construction of the church was funded by voluntary donations, both in money and in materials donated by various people. He testified that he knew that Jedlikowski had donated bricks for the construction of the church, and that Steckiewicz had given the church building committee the parcel on which the church was erected.

The fifth witness, Rudolf Wierzchlejski, testified that in 1915 in Nikolsk-Ussuriysky he met with Steckiewicz, from whom he learned that he had purchased a parcel and donated it with the aim to erect a church on it. On his part, Wierzchlejski praised such behaviour and undertook to donate stone for the construction of the church. The witness also said that when work was commenced, people donated money and materials for the construction. In total, taking into account both money and materials, about 30,000 roubles were collected. The management and supervision of the church construction were entrusted to Steckiewicz. He also received and spent, as an authorised member of the church building committee, all the money that was available to the committee. The witness testified that he knew that Steckiewicz had taken back the parcel he had donated for the sole reason that the new committee had started demanding a financial report from him. However, the defendant did not present it, but submitted bills to the committee. The money for the company which Chen Moo worked for was put in by the committee members when Steckiewicz was no longer the chairman. Wierzchlejski also stated that Steckiewicz was authorised to sole representation in respect of the church construction, and disposed of social resources acting individually.

Another witness, Józef Cudzyński, testified that as a member of the church building committee's review committee, he knew from the documents that Steckiewicz had made a formal statement that he donated a plot of land to the Roman Catholic parish to erect a church on it. The parcel was handed over to the parish for its disposal and the construction of the church, financed from the gifts donated by various people in the form of cash and materials, was started.

${ }^{64}$ In the court public records, he appears as Ченмуy. 
He testified that Steckiewicz, along with other prominent Catholic inhabitants, was actively involved in the construction of the church. The witness also said that because of his peculiar character and as a result of failing to submit a report on the spending of money, which had been demanded by the committee, Steckiewicz was forced to resign from all his positions connected with the construction. Cudzyński revealed that the donation of the plot had not been legalized due to communication difficulties with the Roman Catholic Consistory in St. Petersburg, as a result of the outbreak of the revolution in 1917. Thus, the property title was not transferred to the parish. As a result of leaving the church building committee, Steckiewicz turned to the court demanding that he be granted the property title to the church and that the parish be evicted from the buildings on the plot, i.e. from the apartment at the church and the school. Due to the poor defence on the church side, Steckiewicz achieved a favourable court decision. It was resolved to relocate the parish and recognize the entrepreneur as the owner of the entire real property. This was because the court relied solely on the article stating that buildings are deemed to be the property of the owner of the plot. On the other hand, Steckiewicz proved his property title to the plot by providing his contract of purchase.

The witness Zinowiy Shalevitch testified that Steckiewicz obtained the plot from a company in which Ivan Orlov ${ }^{65}$ had some shares only because he had promised to hand it over for the construction of the church.

The eighth witness, Apollon Józefowicz, testified that the money to erect the church was collected using lists. How much money had been collected, the witness did not know. He explained that a committee was established for this purpose, which also included Steckiewicz, later elected to be its chairman. The committee repeatedly demanded a report from the chairman's activity, but he always avoided submitting it. The witness stated that he knew that the committee had organized the printing of photographs of the church for sale. They were sold by Steckiewicz, but he submitted no settlement of accounts in this regard.

The witness Franc Wyszyński testified that at the parishioners' initiative donation for the church construction had been collected, however, he did not know the amount. He pointed out that bricks, stone and wood had been donated.

The last witness, Feliks Balcerzak, testified that he knew that the church was built from donations, both in the form of money and building materials. At the beginning, a total of about 16,000 roubles was raised. The construction of the church began in 1918 and the money collection was continued. At that time, Steckiewicz was the chairman of the committee and had social funds at his disposal, but he failed to submit any financial report, disregarding the committee's demands. ${ }^{66}$

${ }^{65}$ It was a group of four people, including Orlov, that sold Steckiewicz the parcel on which, subsequently, the church was erected, for 4,500 roubles. Orlov was called as a witness to court, but for unknown reasons he failed to appear at the hearing.

${ }^{66}$ RSHAFE, ф. 614, о. 1, д. 7, Копия протокола мирового судьи 1-го участка Никольск-Уссурийского уезда по иску Костельного Комитета. 
The court public record of 6 December 1921 is the last document kept in collection no. 614 in the Russian State Historical Archive of the Far East in Vladivostok. For this reason, the verdict remains unknown. It may not have been delivered at all, which could have been influenced by the political situation in the Far East of Russia, connected with the civil war. It should be borne in mind that Nikolsk-Ussuriysky was at that time within the borders of Priamursky Zemsky Krai governed by the "Whites", whose armed forces fought both with the Bolshevik guerrilla and the army of the Far Eastern Republic. In the already mentioned work Harsh Vineyard: Far East, Miroslava Yefimova reported that Feliks Steckiewicz did not enjoy the ownership of the church for long (hence, it would follow that the court either did not deliver the verdict, or delivered one to the entrepreneur's benefit). In September 1922, General Mikhail Diterikhs ${ }^{67}$ returned the church to the Roman Catholic parish, believing that it had been "shamelessly seized" by Steckiewicz. In addition, the general obliged the unrealised donor to pay the parish 5,000 roubles. A commission supposed to recover this amount from Steckiewicz's estate even started its work. However, it was never completed. On 25 October, the People's Revolutionary Army of the Far Eastern Republic entered Vladivostok, and the following month Soviet power was established throughout Primorye. ${ }^{68}$ At that time, Gen. Diterikhs emigrated to China (to Manchuria). Feliks Steckiewicz did the same. ${ }^{69}$

As far as the church is concerned, it can be learned from the Internet forums of the Ussuriysk inhabitants that in 1932 the City Executive Committee decided to demolish several places of worship in the city. Among them was also the Catholic church. However, it was not destroyed at that time and, although without the cross, it remained in its place until the 1950s. At first, it housed a club, then a warehouse. ${ }^{70}$

The cited documents present a twofold image of the Polish/Catholic community in Nikolsk-Ussuriysky. On the one hand, it succeeded, despite its small number, in completing the erection of a sizeable stonebuilt church using its own resources. The community probably had good contacts with other ethnic groups, as illustrated by the fact that the local Russians and Chinese supplied construction

${ }^{67}$ Mikhail Diterikhs was one of the chief commanders of the "Whites" in Siberia and the Far East. In March 1918, while in Ukraine, he became commander of the Czechoslovak Corps, with which he reached Vladivostok. Diterikhs supported Admiral Alexander Kolchak, who appointed him as a supervised the Sokolov's investigation of the murder of Tsar Nicholas II and his family. At the end of July 1922, he was appointed administrator of Priamursky Zemsky Krai and, at the same time, the command of armed forces was entrusted to him. In October 1922, however, Vladivostok was conquered by the People's Revolutionary Army of the Far Eastern Republic. Diterikhs emigrated to Manchuria, which was then formally part of China, but practically under Japanese control.

68 Primorye - a geographical region of the Russian Federation. It covers the territory of Primorsky Krai and the southern part of Khabarovsk Krai.

69 Efimova, Harsh Vineyard, p. 109.

70 Уссурийск| Исторические фотографии, http://www.skyscrapercity.com/showthread.php?t= 1595252\&page $=18$ (access: 16 September 2016). 
materials for the church at prices lower than the market ones. The local authorities also supported the construction of the church, as evidenced by the donation of a municipal plot for this purpose. When it turned out that it did not suit the Catholics, the city duma agreed to its sale and allocation of the money earned to purchase an appropriate parcel. At the same time, however, it can be clearly seen that many tasks were carried out in a negligent way, without proper organization. The church was built on a parcel the property title to which was ultimately not legally transferred to the Roman Catholic parish. All such matters had to be approved by the Mogilevsky Roman Catholic Spiritual Consistory in Petrograd. However, communication with it was interrupted by the outbreak of the Bolshevik Revolution. It was for this reason that Catholics decided to entrust Feliks Steckiewicz, one of the richest Poles in the city, with the task of erecting the Catholic church in Nikolsk-Ussuriysky. Not only did the construction of the church - funded by the parishioners - commence on a plot of land that formally belonged to him, but also the management of the funds collected was entrusted solely to Steckiewicz with no supervision whatsoever. When he was finally asked to submit a financial report, he took offence at the parish and withdrew from the donation of the parcel. On the basis of the documents presented, it is difficult to say whether the chairman of the committee for the construction of the church appropriated part of the parishioners' money, or mismanaged it. The fact is that he was unable to account for it. As a consequence of the dispute with the parish, Steckiewicz demanded 120,000 roubles for the parcel with the erected church. This amount was significantly inflated. ${ }^{71}$ Two years earlier, in 1916, the entrepreneur had bought it for 4,500 roubles and, at the same time, according to the testimony of one of the witnesses, he was able to do it for the price because he was supposed to donate it for the construction of the Catholic church. In addition, Steckiewicz included in the demanded amount the value of the buildings on the plot, as if they had been erected solely for his financial outlays.

The presented documents allow us to reflect on the relevance of the popular thesis in the literature of the subject, which was put forward by Oleg Kovalenko in 2005 and repeated by Yefimova. Namely, in the spring of 1918, without consulting the committee for the construction of the church, Steckiewicz vigorously proceeded to commence the construction work, which had not been done before. Kovalenko suggested that this was necessary because of the growing strength of the Bolsheviks in Primorye, who could nationalize "bourgeois estates". ${ }^{72}$ This version could only be accepted if Steckiewicz, following the unsuccessful attempt to legally hand over the parcel (due to the lack of communication with the Spiritual Consistory in Petrograd), had wanted it to become the property of the Roman

\footnotetext{
${ }^{71}$ One should bear in mind the rampant inflation in Russia at the time. However, it was impossible to find reliable information on the increase in prices between 1916-1918.

72 Efimova, Harsh Vineyard, p. 109.
} 
Catholic parish through the very fact of having a church built on it. Owning the property title to an empty parcel, he would have been afraid of its being requisitioned by the Bolsheviks, which would consequently make the construction of the church impossible. ${ }^{73}$ One argument against such reasoning is, among others, the document of 1918 in which Steckiewicz demanded 120,000 roubles for the parcel along with the church. This proves that the entrepreneur did not engage in a complicated intrigue for fear of Bolshevik policy. The reason for his conduct was more prosaic: it was due to his difficult character, which thwarted the agreement with the committee, as well as financial matters. This version seems to be even more likely, if attention is paid to the witnesses' testimony before the court. They emphasised that Steckiewicz refused to donate the plot for the construction of the church only when the committee began demanding from him that he should present a report on the spending of social funds. Therefore, it seems that the Polish community became divided not for political reasons, but because of the financial matters related to the accounting for the costs of the construction of the church.

\section{The Construction of the Catholic Church in Nikolsk-Ussuriysky (Ussuriysk) in the Light of the Russian State Historical Archive of the Far East in Vladivostok}

\section{Abstract}

The article presents documents pertaining to the construction of a Catholic church at Ussuriysk, kept in the Russian State Historical Archive of the Far East in Vladivostok. The documents span the period between 1912 and 1921. They reveal that the Municipal Duma of Ussuriysk was in favour of the construction of a Catholic church in the town; this could be concluded from the fact that they gave free of charge a lot of land to the community of Catholics for that purpose. But the church was built on the lot belonging to a local entrepreneur, a certain Feliks Steckiewicz, for it was more suited to the needs of the Catholics due to its central location in the town. Initially Steckiewicz declared his intention to give the land to the Catholic parish. And because he was held in high esteem by the local community, he was put at the lead of a committee for the construction of the church. This made it possible for him to spent money collected by the faithful without any control. A conflict within the committee started when its members demanded financial reports. Steckiewicz never presented a financial statement; in addition, he withdrew his donation of land and demanded that the Catholic parish paid him for the church building constructed on his lot.

Archival documents disprove the thesis, popular in the literature on the subject, that Steckiewicz's actions were motivated by his fear of a growing strength of the Bolsheviks in Primorsky Krai and a possibility of nationalisation. The reasons for his actions were more mundane - his character that made it impossible for him to reach an agreement with the committee, and financial matters. This seems all the more probable in the light of testimonies of witnesses in court. They emphasised that Steckiewicz withdrew his donation of land to the church only after the committee requested financial reports and tallies of his expenses. It seems,

73 The Bolsheviks took power in Primorye after the Bolshevik Revolution, but in mid-1918 they were driven out of the area by the Czechoslovak Corps and the troops of the "Whites". 
therefore, that the local Polish community quarrelled not for political reasons, but financial matters related to the construction of a church.

\title{
Дело о строительстве католического костела в Никольск-Уссурийском (Уссурийске) в свете документов из Российского государственного исторического архива Дальнего Востока во Владивостоке \\ Аннотация
}

В статье были представлены документы, касающиеся строительства католического костела в Уссурийске (Никольск-Уссурийском), которые находятся сейчас в фондах Российского государственного исторического архива Дальнего Востока во Владивостоке. Документы охватывают период с 1912 по 1921 г. Из них следует, что Городская дума была благосклонно настроена к строительству католического костела. Об этом свидетельствует, хотя бы то, что она бесплатно передала участок католической общине для строительства на нем храма. Однако костел построили на участке Ф. Стецкевича, местного предпринимателя, так как его земля в большей степени отвечала потребностям католиков благодаря своему расположению в центральной части города. Ф. Стецкевич изначально изъявлял желание передать недвижимость католическому приходу. Благодаря уважению местных католиков, он также возглавил комитет по строительству костела. Находясь на этом посту, он мог без какого-либо контроля тратить деньги, собираемые среди верующих. Конфликт в комитете начался, когда его члены стали требовать у своего председателя представить финансовый отчет. Ф. Стецкевич никогда его не предъявил, а кроме того он отменил свою дарственную и стал требовать у католического прихода денег за костел, построенный на его участке.

Архивные документы противоречат популярному в литературе предмета тезису, что деятельность Ф. Стецкевича была мотивирована опасением возрастающей силы большевиков в Приморье и возможным проведением ими национализации. Причина его поведения была более прозаична - его характер, из-за которого не мог найти общий язык с комитетом, а также финансовые дела. Это кажется тем более правдоподобным, если обратить внимание на показания свидетелей в суде. Они подчеркивали, что Ф. Стецкевич отказался дарить участок под строительство костела только, когда комитет стал требовать с него представить отчет об израсходованных общественных деньгах. Получается, что польская диаспора поссорилась не по политическим причинам, но из-за финансовых дел, связанных с отчетом издержек на строительство костела.

Перевод Агнешка Поспишил

\section{Bibliography}

\section{Archival material}

\author{
Archival notations: \\ o. - opis' - inventory \\ д. - delo - file \\ л. - list, listy - folio, folios \\ ф. - fond - collection
}




\section{RSHAFE - Russian State Historical Archives of the Far East}

RSHAFE, ф. 614, о. 1, д. 2, Переписки и план участка взятого под постройку костела в Никольск-Уссурийске, л. 1.

RSHAFE, ф. 614, о. 1, д. 2, Переписки и план участка взятого под постройку костела в Никольск-Уссурийске, л. 2.

RSHAFE, ф. 614, о. 1, д. 2, Переписки и план участка взятого под постройку костела в Никольск-Уссурийске, л. 3.

RSHAFE, ф. 614, о. 1, д. 2, Переписки и план участка взятого под постройку костела в Никольск-Уссурийске, л. 7.

RSHAFE, ф. 614, о. 1, д. 2, Переписки и план участка взятого под постройку костела в Никольск-Уссурийске, л. 9.

RSHAFE, ф. 614, о. 1, д. 2, Переписки и план участка взятого под постройку костела в Никольск-Уссурийске, л. 10.

RSHAFE, ф. 614, о. 1, д. 2, Переписки и план участка взятого под постройку костела в Никольск-Уссурийске, л. 11.

RSHAFE, ф. 614, о. 1, д. 2, Переписки и план участка взятого под постройку костела в Никольск-Уссурийске, л. 12.

RSHAFE, ф. 614, о. 1, д. 2, Переписки и план участка взятого под постройку костела в Никольск-Уссурийские, л. 14.

RSHAFE, ф. 614, о. 1, д. 2 Переписки и план участка взятого под постройку костела в Никольск-Уссурийске, л. 16.

RSHAFE, ф. 614, о. 1, д. 2, л. 18, Письмо начальнику 3-го района милиции в г. Никольске. RSHAFE, ф. 614, о. 1, д. 2 Переписки и план участка взятого под постройку костела в Никольск-Уссурийске, л. 19.

RSHAFE, ф. 614, о. 1, д. 3, л. 18, Протокол с 7 ноября 1916 г.

RSHAFE, ф. 614, о. 1, д. 3, л. 19, Протокол с 2 февраля 1919 г.

RSHAFE, ф. 614, о. 1, д. 3, л. 21, Протокол заседания костельного Комитета.

RSHAFE, ф. 614, о. 1, д. 3, л. 22, Заседание Комитета по постройке костела.

RSHAFE, ф. 614, о. 1, д. 3, л. 25, Заявление Феликса Стецкевича.

RSHAFE, ф. 614, о. 1, д. 3, л. 26, Заседание Комитета по постройке костела.

RSHAFE, ф. 614, о. 1, д. 3, л. 28, Протокол заседания поляков-католиков НикольскУссурийска.

RSHAFE, ф. 614, о. 1, д. 3, л. 32, Указ.

RSHAFE, ф. 614, о. 1, д. 3, л. 33, Заседание Комитета по постройке костела.

RSHAFE, ф. 614, о. 1, д. 3, л. 38, Заседание Комитета по постройке костела.

RSHAFE, ф. 614, о. 1, д. 4, л. 1, Письмо с 17 октября 1918 г.

RSHAFE, ф. 614, о. 1, д. 4, л. 2, Указ.

RSHAFE, ф. 614, о.1, д. 4, л. 4, Подписка Михаила Стецкевича.

RSHAFE, ф. 614, о. 1, д. 4, л. 5, Подписка Яна Едликовского.

RSHAFE, ф. 614, о. 1, д. 5, Акты комисии по постройке костела в Никольск-Уссурийске.

RSHAFE, ф. 614, о. 1, д. 6, Протоколь общего собрания прихожан Никольск-Уссур. костела Протокол, л. 1.

RSHAFE, ф. 614, о. 1, д. 7, Копия протокола мирового судьи 1-го участка НикольскУссурийского уезда по иску Костельного Комитета.

RSHAFE, ф. 614, о. 1, д. 8, Смета на постройку Римско-католического костела, л. 1. 


\section{Secondary literature}

Efimova M., Harsh Vineyard: A History of Catholic Life in the Russian Far East, Bloomington, 2008.

Jelčaninov O., Ustanovení katolické církevní organizace, její vývoj na Ruském Dálném Východè, od konce 19. století do 30. let Sovětského období, Olomouc, 2013.

Nowak E., Duszpasterstwo wojskowe katolickie i prawosławne w Rosji 1832-1914, Wilno, 1934. Proboszczowie, http://web.diecezja.wloclawek.pl/parafia/ciechocinek/proboszczowie.html.

Всесоюзная перепись населения 1926 года. Национальный состав населения по регионам РСФСР, http://demoscope.ru/weekly/ssp/rus_nac_26.php?reg=1410.

Калинин В., Краткий исторический очерк города Никольск-Уссурийского, Владивосток, 2015.

Первая всеобщая перепись населения Российской Империи 1897 г. Распределение населения по родному языку и уездам Российской Империи кроме губерний Европейской России, http://demoscope.ru/weekly/ssp/emp_lan_97_uezd.php?reg=691.

Уссурийск | Исторические фотографии, http://www.skyscrapercity.com/showthread.php?t= 1595252 \&page $=18$.

Хвалин А., Из истории римо-католичества на Дальнем Востоке, http://ruskline.ru/analitika/2011/12/09/vlast_rimskogo_pontifika_protiv_vlasti_russkogo_carya/.

Численность населения Российской Федерации по муниципальным образованиям, httр:// www.gks.ru/wps/wcm/connect/rosstat_main/rosstat/ru/statistics/publications/catalog/afc8ea004d56a39ab251f2bafc3a6fce.

Przemysław Adamczewski (b. 1981), the Institute of Political Studies of the Polish Academy of Sciences (since 2016). He is a graduate of international relations at Adam Mickiewicz University, Poznań. In 2010 he was awarded PhD degree for the preparation of a thesis devoted to the Karabakh problem in the politics of Azerbaijan after 1991. In 2011 the thesis was awarded Prof. Robert Mrozewicz Prize for best doctoral dissertation on international relations and diplomacy. In 2011-2013 he was vice-chancellor of the Higher School of Humanities and Economics at Sieradz. In 2013-2015 was employed at Ivane Javakhishvili Institute of History and Ethnology in Tbilisi, where he worked on a research project "Mythologization of historical memory as a determinant of ethnic conflicts in the Caucasus" (adprzem@op.pl). 